\title{
Mass rearing diet for the pink bollworm Pectinophora gossypiella (Lepidoptera: Gelechiidae) and its susceptibility to insecticidal $\mathrm{Bt}$ proteins
}

\author{
K. Muralimohan ${ }^{1}$, S.P. Kamath ${ }^{1}$, K.S. Mohan ${ }^{2 *}$, K.C. Ravi ${ }^{2}$, \\ Farah Deeba ${ }^{2}$, Sakuntala Sivasupramaniam ${ }^{3}$ and \\ Graham P. Head ${ }^{3}$ \\ ${ }^{1}$ Monsanto India Limited, Ahura Centre, 5th Floor, 96 Mahakali Caves \\ Road, Andheri (East), Mumbai 400 093, India: ${ }^{2}$ Monsanto Research \\ Centre, No. 44/2A, Vasanth's Business Park, Bellary Road, NH-7 \\ Hebbal, Bangalore 560092, India: ${ }^{3}$ Monsanto Company, 800 North \\ Linderbergh Boulevard, St Louis, Missouri 63167, USA
}

(Accepted 25 May 2009)

\begin{abstract}
A study was carried out to develop a diet for mass rearing of the pink bollworm Pectinophora gossypiella (Saund.) and optimize bioassays for testing the bollworm's sensitivity to two insecticidal proteins from Bacillus thuringiensis (Bt). A P. gossypiella colony was established in the laboratory from field collections and its developmental biology was compared on various test diets. Larvae reared on a diet of cottonseed and chickpea flours for the first 10 days and subsequently on pieces of okra attained rapid growth and development. This two-phase diet has been used for successful laboratory rearing of 51 generations of the bollworm. Neonates were found to be sensitive to both the $B t$ proteins Cry1Ac and Cry2Ab2, which are produced by the transgenic $B t$ cotton products Bollgard ${ }^{\mathrm{TM}}$ and Bollgard $\mathrm{II}^{\mathrm{TM}}$.
\end{abstract}

Key words: mass culture, Pectinophora gossypiella, Bt proteins, Cry1Ac, Cry2Ab2, Bt cotton

\section{Introduction}

The pink bollworm Pectinophora gossypiella (Saund.) (Lepidoptera: Gelechiidae) is one of the most important pests of cotton and is distributed throughout the world's cotton-growing areas (Pearson, 1958). The bollworm lays its eggs on squares, flowers or green bolls. Its destructive larval stage is usually buried within the cotton's fruiting bodies, unreachable by insecticidal sprays. Larvae feed on squares, flowers and bolls, including the seeds within bolls. Damage to squares and flowers

*E-mail: k.s.mohan@monsanto.com can be substantial if infestation occurs in the earlyand mid-growing season (Hari Prasad, 1999). They web the cotton flower petals, imparting a characteristic 'rosette' appearance. Feeding within the boll results in malformation, rotting, premature or partial boll opening, reduction in fibre length and overall reduced quality of the cotton crop due to staining of the lint (Ingram, 1995).

Bollgard $^{\mathrm{TM}}$, a transgenic Bt cotton, was approved for commercial cultivation in India in 2002. It protects against the primary bollworm complex comprising the cotton bollworm Helicoverpa armigera (Lepidoptera: Noctuidae), the spotted bollworm Earias vittella (Lepidoptera: Noctuidae) and the 
pink bollworm P. gossypiella. Bollgard $\mathrm{II}^{\mathrm{TM}}$, a twogene $B t$ cotton, was approved for commercialization in India in 2006. During the 2008 growing season, $B t$ cotton was grown on a total of 7.6 million ha in the cotton belts of north, central and south India (James, 2008) constituting 79\% of the total cotton area (9.6 million ha) in India. In 2008, some 158 singlegene and 63 two-gene $B t$ cotton hybrids belonging to three $B t$ cotton technology providers were available on the market in India.

As a resistance management measure, the susceptibility of multiple geographical populations of $H$. armigera and E. vittella was studied for 2 years before the commercial approval of $B t$ cotton in India. Resistance monitoring in $H$. armigera is conducted annually (Kranthi and Kranthi, 2008). However, similar studies on P. gossypiella have not been carried out in India, primarily because of difficulties with its mass rearing in the laboratory.

The study reported here had two aims: (1) to develop a mass-rearing diet for $P$. gossypiella using locally available ingredients and (2) to optimize the bioassay for testing $B t$ proteins against the bollworm.

The test diets used some of the ingredients tested by previous researchers (Adkisson et al., 1960; Raulston, 1971; Patana, 1977; Navarajan Paul et al., 1987), and bollworm development was compared with that on commercial diet premixes obtained from the USA.

\section{Materials and methods}

\section{Starter culture}

A field culture of P. gossypiella (around 500 larvae) was obtained from mature or open bolls collected from infested non-transgenic cotton fields within the Dharwad district in India. The larvae were fed on green bolls maintained in plastic trays in an environmental chamber at $27 \pm 1{ }^{\circ} \mathrm{C}$, RH $60 \pm 5 \%$ and $9 \mathrm{~h}$ light $-15 \mathrm{~h}$ dark photoperiod until pupation. Healthy pupae were sexed and stored in plastic vials $(4 \mathrm{~cm}$ diameter and $5 \mathrm{~cm}$ height) with a filter paper disc at the bottom and a lid with a mesh window. These vials were retained in an incubator at $28 \pm 1^{\circ} \mathrm{C}$ until adult emergence.

\section{Rearing}

Twenty-five pairs of adult $P$. gossypiella were released into one oviposition jar (transparent plastic container of $28 \mathrm{~cm}$ height and $24 \mathrm{~cm}$ diameter). Adults were fed on a mixture of 'Proteinex' (a protein supplement), honey and distilled water (1:1:3 ratio) delivered in a ball of absorbent cotton placed in a small glass dish inside the oviposition jar. Another cotton ball dipped in distilled water was also placed in each jar. Each jar also contained a small twig of conventional cotton bearing a few leaves and squares, which served as a substratum for adults to rest and oviposit. The cut end of the twig was kept in water and inserted through a hole in the cap of a small plastic vial. The opening of the oviposition jar was covered with white cotton cloth fastened with rubber bands. Oviposition jars were maintained in an environmental chamber and adults were transferred to a fresh jar every third day. Moths laid eggs in leaf axils, on the squares and on the ventral surface of the leaves. Eggs were transferred to plastic vials $(5 \mathrm{~cm}$ height and $4 \mathrm{~cm}$ diameter) with plastic mesh lids. These vials were placed in an incubator at $28 \pm 1^{\circ} \mathrm{C}$. Vials were examined daily and neonates were transferred to experimental diets using a fine hair brush.

\section{Experimental diets}

Two commercial diet premixes for rearing PBW were imported from the USA, and the development of $P$. gossypiella on the premixes was compared with that on the test diets formulated in our laboratory. Details of the diets used are given in Table 1.

Prepared hot diet was poured into large glass Petri plates $(19 \mathrm{~cm}$ diameter $)$ to a thickness of $1 \mathrm{~cm}$ and allowed to cool and solidify. The solidified diet was diced into $1 \mathrm{~cm}^{3}$ cubes and a cube was placed in each of the 32 wells of an insect culture tray (CD International, Pitman, NJ, USA). Freshly emerged $P$. gossypiella neonates were released onto diet cubes at 1 neonate/well and reared until pupation.

Wherever okra was used as the second-phase diet, 10-day-old larvae were transferred to slices of okra (Table 1). Pupae were sexed (Navarajan Paul et al., 1979), weighed and kept individually in plastic vials until adult emergence.

\section{Observations}

Larval period, pupal weight, pupal period, generation time, pupal malformation, adult emergence, adult malformation, adult longevity and sex ratio were recorded for each diet. One-way ANOVA in Microsoft Excel was used to compare the performance of the bollworm stages on the different diets.

\section{Bioassay with Bt protein Cry1Ac}

A freeze-dried commercial formulation of MVP-II ${ }^{\circledR}$ (Cell-Cap ${ }^{\circledR}$ encapsulation system by Mycogen, San Diego, California, USA) was used as the source 
Table 1. Experimental and commercially available diets used for mass rearing of the pink bollworm Pectinophora gossypiella

Diet, source and composition

1. Southland pink bollworm diet premix

Southland Products, Inc., Ark, USA; composition not disclosed by manufacturer

2. Southland multi-species Lep diet

Southland Products, Inc., Ark, USA; composition not disclosed by manufacturer

3. Cottonseed flour diet

Ingredients for 11 of diet:

A. $60 \mathrm{~g}$ cottonseed flour; $40 \mathrm{~g}$ yeast extract (Loba Chemie Pvt Ltd, Mumbai, India); $400 \mathrm{ml}$ water

B. $15 \mathrm{~g}$ agar (Fisher Scientific); $400 \mathrm{ml}$ water

C. Antimicrobials: $0.1 \mathrm{~g}$ carbendazim (Bavistin 50\% WP; Bayer Crop Science); $1.0 \mathrm{~g}$ methyl parahydroxybenzoate (Loba Chemie); $0.5 \mathrm{~g}$ sorbic acid (Loba Chemie); $0.5 \mathrm{~g}$ streptomycin sulphate (Nicholas Piramal India Ltd)

D. Micro-ingredients: 0.1 g L-cys (HiMedia, Mumbai, India); $2 \mathrm{ml}$ polybion (Cradel Pharmaceuticals Pvt Ltd, Kolkata, India); $2.5 \mathrm{~g}$ Wesson salt mixture*; $0.5 \mathrm{~g}$ cholesterol (Qualigens, Mumbai, India); $2.0 \mathrm{~g}$ L-ascorbic acid (Loba Chemie)

*Wesson salt mixture (for $400 \mathrm{~g}$ ): $42 \mathrm{~g}$ sodium chloride; $48 \mathrm{~g}$ potassium chloride; $124 \mathrm{~g}$ potassium hydrogen phosphate; $59.6 \mathrm{~g}$ magnesium phosphate; $84 \mathrm{~g}$ calcium carbonate; $36 \mathrm{~g}$ magnesium sulphate; $5.88 \mathrm{~g}$ ferric phosphate; $0.1 \mathrm{~g}$ manganese sulphate; $0.16 \mathrm{~g}$ potassium aluminium phosphate; $0.2 \mathrm{~g}$ sodium fluoride; $0.02 \mathrm{~g}$ potassium iodide

4. Cottonseed flour diet + okra

Same as No. 3 except that the pink bollworm neonates were reared on cottonseed diet for 10 days and then transferred onto cut okra fruit and reared to pupation. Okra fruits (about $15 \mathrm{~cm}$ long) washed with sterile water, blotted using a clean cloth and then cut into about $2.5 \mathrm{~cm}$-long pieces. Okra pieces were changed every 3 days

5. Cottonseed flour and chickpea flour diet

Same as diet No. 3 except that a chickpea and cottonseed flour mixture was used at 1:1 by weight

6. Cottonseed flour and chickpea flour diet + okra

Same as diet No. 5 except that the pink bollworm neonates were reared on a mixture of cottonseed and chickpea flour diet for 10 days and then transferred onto cut okra fruit until pupation. Okra pieces were changed every 3 days

of Cry1Ac protein. The formulation contained $19.7 \%(\mathrm{w} / \mathrm{w})$ of Cry1Ac protein, as determined using the diet-incorporation method (Sims et al., 1996). A primary stock solution for Cry1Ac was prepared by vortexing $12.69 \mathrm{mg}$ MVP-II powder in $10 \mathrm{ml}$ of $0.2 \%$ agar solution. Seven serial dilutions were prepared in sterile water in centrifuge tubes $(50 \mathrm{ml})$ using threefold dilution.

Southland multi-species Lep diet ${ }^{\mathrm{TM}}$ was prepared in sterile glass bottles and kept in a water bath at $60^{\circ} \mathrm{C}$. The diluted Cry1Ac standards $(3.28 \mathrm{ml})$ in each of the serial dilution tubes were thoroughly vortexed with $13.12 \mathrm{ml}$ of warm diet $\left(60^{\circ} \mathrm{C}\right)$ and approximately $1 \mathrm{ml}$ was poured into each well of insect bioassay trays (CD International Trays $^{\mathrm{TM}}$, MA, USA). The final concentrations of Cry1Ac were 1.5, 0.5, 0.167, 0.056, 0.019, 0.006 and $0.002 \mu \mathrm{g} / \mathrm{ml}$ of diet. The diet trays were allowed to dry for $45 \mathrm{~min}$.

Active $P$. gossypiella neonates (1 neonate/well) were transferred onto the solid diet with a fine hair brush on a laminar flow clean air bench. Bioassay trays were then covered with self-adhesive Pull-NPeel $^{\mathrm{TM}}$ tabs (CD International) and transferred to an incubator maintained at $27 \pm 1{ }^{\circ} \mathrm{C}$. Sixteen larvae were exposed to each of the various Cry1Ac concentrations and an untreated control. The entire assay was replicated 10 times.

\section{Bioassay with Bt protein Cry2Ab2}

The source of Cry2Ab2 protein was leaf powder from transgenic maize plants (event MON 84 006) containing Cry $2 \mathrm{Ab} 2$ protein $(3 \mathrm{mg} / \mathrm{g}$ of corn leaf powder). The Cry2Ab2 protein produced in transgenic maize leaves is a very stable source of Cry2Ab2 protein, and has been used in bioassays and resistance monitoring studies globally. Assay methods and the test arena were identical to those used in the Cry1Ac assays.

The primary stock solution for Cry2Ab2 was prepared by vortexing $5.2 \mathrm{mg}$ maize leaf powder in $125 \mu \mathrm{l}$ of sterile water. Seven serial dilutions were prepared in sterile water in centrifuge tubes $(50 \mathrm{ml}$ capacity) using twofold dilutions. Diluted Cry2Ab2 standard remaining in each of the serial dilution tubes $(3.28 \mathrm{ml})$ was vortexed with $13.12 \mathrm{ml}$ of warm diet $\left(60^{\circ} \mathrm{C}\right)$, and approximately $1 \mathrm{ml}$ of the mixture was poured into each well of the insect bioassay trays. The final concentrations of Cry $2 \mathrm{Ab} 2$ in 


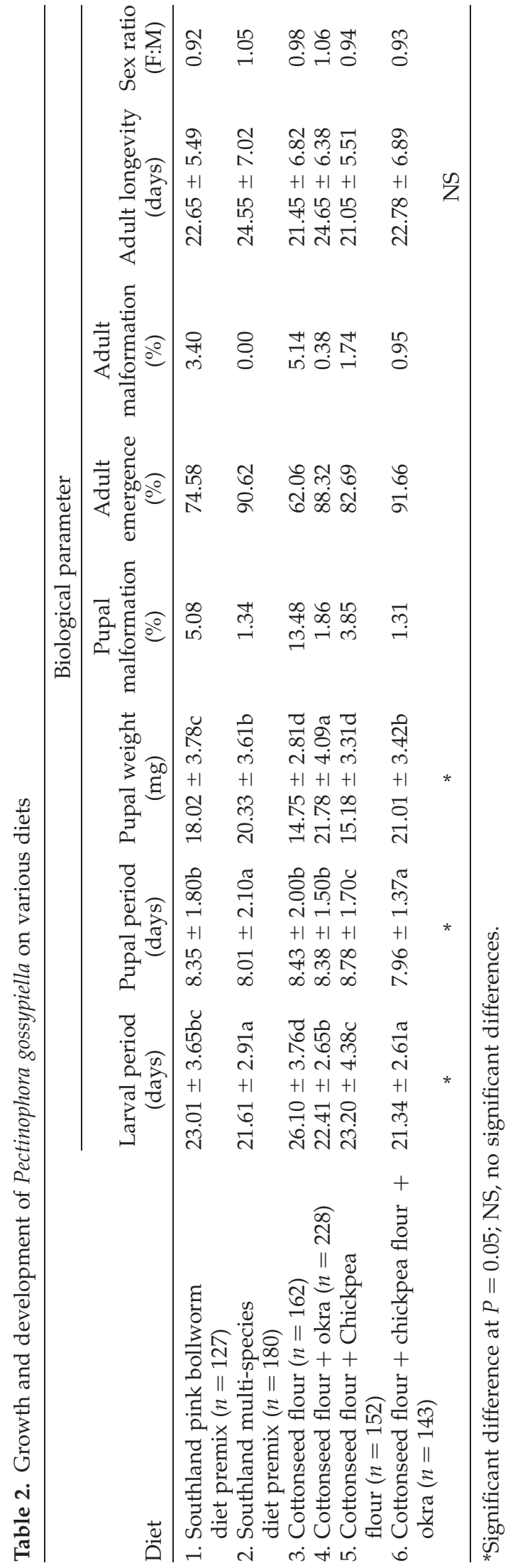

diet were $0.2,0.1,0.05,0.025,0.013,0.006$ and $0.003 \mu \mathrm{g} / \mathrm{ml}$ of diet. Sixteen larvae were exposed to each of the various Cry2Ab2 concentrations and an untreated control. The entire assay was replicated 10 times using neonates that had hatched within $4 \mathrm{~h}$.

\section{Observations for Bt assays}

Mortality, instar (determined from head capsule size) and group weight of surviving larvae were recorded 21 days after infestation (Tabashnik et al., 2000). Probit analysis, carried out using SPSS software (SPSS Inc., Chicago, Illinois, USA), was used to calculate:
lethal concentrations ( $\mathrm{LC}_{50}$ and $\mathrm{LC}_{90}$ ),
moult-inhibitory concentration $(\mathrm{MIC})=$ concentration of protein that severely limited larvae from developing beyond the first instar, and
inhibitory concentration (IC) $=$ concentration of protein that prevented larvae from reaching the third instar.

Log-linear regression analysis of the data using JMP software (SAS Institute Inc., Cary, North Carolina, USA) was used to calculate:

effective concentration $(\mathrm{EC})=$ concentration of protein that reduced larval weight by a certain percentage relative to untreated controls.

The above concentration-response parameters were expressed in $\mu \mathrm{g}$ of Cry1Ac or Cry $2 \mathrm{Ab} 2 / \mathrm{ml}$ of diet.

\section{Results and discussion}

\section{Growth and development on various diets}

Growth and development parameters for P. gossypiella on the six different diets are presented in Table 2.

Larval period (five instars) was shortest on a diet of cottonseed/chickpea flours + okra $(21.34 \pm 2.61$ days); this period was comparable to that for bollworm larvae reared on the Southland multispecies (SM) diet. The shortest pupal period (7.96 \pm 1.37 days) was observed on cottonseed/ chickpea flours + okra. As such, P. gossypiella completed its life cycle fastest on a cottonseed/ chickpea flours + okra diet. Larval and pupal periods were the longest on sole cottonseed flour diet, which gave the slowest overall development (34.53 \pm 4.49 days).

Pupal weight, an indicator of food conversion efficiency during larval stages, was highest on the cottonseed flour + okra diet $(21.78 \pm 4.09 \mathrm{~g})$. Pupal weights reached with cottonseed and chickpea 
Table 3. Concentration-dependent response of Pectinophora gossypiella neonates to Cry1Ac protein

\begin{tabular}{|c|c|c|c|}
\hline Parameter & $\begin{array}{c}\mathrm{LC}_{50} / \mathrm{MIC}_{50} / \mathrm{IC}_{50} / \mathrm{EC}_{50} \\
\text { (in } \mu \mathrm{g} \text { Cry } 1 \mathrm{Ac} / \mathrm{ml} \text { diet } \pm \mathrm{SD} \\
95 \% \text { fiducial limits) }\end{array}$ & $\begin{array}{c}\mathrm{LC}_{90} / \mathrm{MIC}_{90} / \mathrm{IC}_{90} / \mathrm{EC}_{90} \\
\text { (in } \mu \mathrm{g} \text { Cry } 1 \mathrm{Ac} / \mathrm{ml} \text { diet } \pm \mathrm{SD} \\
95 \% \text { fiducial limits) }\end{array}$ & $\chi^{2} \pm S D$ \\
\hline Lethal concentration (LC) & $0.040 \pm 0.01(0.023-0.069)$ & $0.41 \pm 0.31(0.193-1.521)$ & $4.314 \pm 1.34$ \\
\hline Moult-inhibitory concentration (MIC) & $0.024 \pm 0.01(0.014-0.039)$ & $0.165 \pm 0.06(0.088-0.466)$ & $3.728 \pm 1.79$ \\
\hline Inhibitory concentration (IC) & $0.011 \pm 0.005(0.007-0.016)$ & $0.045 \pm 0.02(0.026-0.118)$ & $3.283 \pm 1.74$ \\
\hline Effective concentration (EC) & $0.004 \pm 0.002(0.003-0.008)$ & $0.036 \pm 0.026(0.031-0.044)$ & NA \\
\hline
\end{tabular}

Values are expressed as $\mu \mathrm{g}$ Cry1Ac/ml of diet $(\mathrm{ppm}) ; n=160$ (total number of $P$. gossypiella neonates exposed to a single concentration of Cry1Ac); no. of graded concentrations per assay =7; no. of assays $=10$. NA, not available; $\chi^{2}: P \leq 0.017$.

flours + okra and SM diets were not significantly different $(P=0.05)$.

Pupal malformation was high when P. gossypiella was reared solely on cottonseed flour diet $(13.48 \%)$, but decreased to $1.86 \%$ when larvae reared on cottonseed flour were transferred to okra fruit slices after 10 days. Pupal malformation was lowest $(1.31 \%)$ on cottonseed/chickpea flours + okra diet.

Maximum adult emergence (91.66\%) was recorded on the cottonseed/chickpea flours + okra diet. Adult emergence was greater when larvae were reared on cottonseed flour diet followed by okra $(88.32 \%)$, compared with a sole cottonseed flour diet $(62.06 \%)$. Five per cent of emerged adults were malformed on cottonseed flour diet, but this was reduced to $0.38 \%$ when 10 -day-old larvae reared on cottonseed flour were transferred to okra.

It appears that the transfer of 10-day-old larvae from the semi-synthetic diet to cut okra pieces significantly decreased pupal malformation and improved normal adult emergence. This is likely because okra is a natural diet of the insect. In the mass rearing of $P$. gossypiella using the two-step procedure, it is important that the okra has no insecticide residue as such residues can contribute to retarded growth and malformation at the pupal or adult stages.

Adult longevity ranged from 21.05 to 24.65 days, but did not vary significantly across the diets tested. Adult sex ratio was close to 1:1 on all the different diets.

Our results showing superior larval development of P. gossypiella on a diet of cottonseed and chickpea flours when compared with a sole cottonseed flour diet corroborate a study by Navarajan Paul et al. (1987), which recommended that $P$. gossypiella diet should contain chickpea flour and cottonseed flours in a ratio of 1:1.4. Similarly, Hari Prasad (1999) observed growth and development of P. gossypiella at par with natural diet when chickpea and cottonseed flours were used in a ratio of 1:1.4. However, fungal contamination was a frequently encountered problem with our experimental diets. Such contamination was minimal on the commercial SM diet, and for this reason commercial diet was used for evaluating the sensitivity of the bollworm to Cry1Ac and Cry2Ab2 proteins.

\section{Sensitivity of P. gossypiella to Cry1Ac and Cry2Ab2 proteins}

P. gossypiella neonates were extremely susceptible to Cry1Ac and Cry2Ab2 proteins, as shown by the low lethal concentration (LC), moult-inhibitory concentration (MIC) and inhibitory concentration (IC) values recorded (Tables 3 and 4, respectively).

At the end of the 21-day assay period, some P. gossypiella larvae exposed to Cry1Ac or Cry2Ab2 survived, but almost all survivors were still in their

Table 4. Concentration-dependent response of Pectinophora gossypiella neonates to Cry2Ab2 protein

\begin{tabular}{|c|c|c|c|}
\hline Bioassay parameter & $\begin{array}{c}\mathrm{LC}_{50} / \mathrm{MIC}_{50} / \mathrm{IC}_{50} / \mathrm{EC}_{50} \\
\text { (in } \mu \mathrm{g} / \mathrm{ml} \text { Cry2Ab2/ml of diet } \pm \mathrm{SD} \\
\text { 95\% fiducial limits) }\end{array}$ & $\begin{array}{c}\left(\mathrm{LC}_{90} / \mathrm{MIC}_{90} / \mathrm{IC}_{90} / \mathrm{EC}_{90}\right) \\
\text { (in } \mu \mathrm{g} / \mathrm{ml} \text { Cry2Ab2/ml of diet } \pm \mathrm{SD} \\
95 \% \text { fiducial limits) }\end{array}$ & $\chi^{2} \pm \mathrm{SD}$ \\
\hline Lethal concentration (LC) & $0.051 \pm 0.01(0.036-0.073)$ & $0.18 \pm 0.03(0.114-0.410)$ & $3.91 \pm 2.69$ \\
\hline $\begin{array}{l}\text { Moult-inhibitory } \\
\text { concentration (MIC) }\end{array}$ & $0.028 \pm 0.01(0.021-0.036)$ & $0.058 \pm 0.01(0.043-0.106)$ & $1.792 \pm 2.06$ \\
\hline Inhibitory concentration (IC) & $0.02 \pm 0.01(0.015-0.028)$ & $0.059 \pm 0.02(0.04-0.115)$ & $6.138 \pm 1.3$ \\
\hline Effective concentration (EC) & $0.003 \pm 0.001(0.010-0.028)$ & $0.056 \pm 0.038(0.058-0.675)$ & NA \\
\hline
\end{tabular}

Values are expressed as $\mu \mathrm{g}$ Cry2Ab2/ml of diet (ppm); $n=160$ (total number of $P$. gossypiella neonates exposed to a single concentration of Cry2Ab2); no. of graded concentrations per assay $=7$; no. of assays $=10$. NA, not available; $\chi^{2}: P \leq 0.018$. 
first instar, and were severely stunted, inactive and weak. These surviving larvae were seen surviving on water condensed on the inner wall of the bioassay tray wells. Because of this characteristic of pink bollworm larvae, it is advisable to use MIC values rather than LC values to evaluate pink bollworm tolerance to $B t$ insecticidal proteins.

Overall, these results indicate that Indian P. gossypiella is extremely sensitive to the $B t$ proteins contained in the transgenic cotton varieties Bollgard and Bollgard II. Baseline studies using the same insecticidal proteins should be conducted with various additional field-collected Indian bollworm populations.

\section{Conclusion}

For the mass culturing of P. gossypiella, a two-step diet was found to be optimal. The first phase consisted of rearing the larvae on a semi-synthetic diet composed of cotton and chickpea flours as the main ingredients for 10 days from emergence, and then on cut okra pieces until pupation. This two-phase diet is made from locally available ingredients and the methodology can be easily adopted by Indian researchers, saving them the importation of expensive diet premixes. This is the first report of using such a diet combination to successfully culture the pink bollworm in the laboratory. A laboratory colony established from field-collected P. gossypiella has now been reared for 51 generations on this diet.

This study also found that $P$. gossypiella neonates were highly susceptible to the $B t$ proteins Cry $1 \mathrm{Ac}$ and Cry2Ab2.

\section{Acknowledgements}

The authors acknowledge the support received from the members of Biotech Product Support Team of Monsanto Research Centre, Bangalore, during the field collection of P. gossypiella, laboratory rearing and conduct of bioassays. The authors also thank Professor Tim Dennehy for his technical inputs and review of the manuscript, and Dr G.C. Unnithan for his advice on insect rearing.

\section{References}

Adkisson P. L., Vanderzant E. S., Bull D. L. and Allison W. E. (1960) A wheat germ medium for rearing the pink bollworm. Journal of Economic Entomology 53, $759-762$.

Hari Prasad K. V. (1999) Ecology and behavioural aspects of the pink bollworm, Pectinophora gossypiella (Saund.) (Lepidoptera: Gelechiidae) infesting cotton. Journal of Entomological Research 23, 149-155.

Ingram W. R. (1995) Pectinophora (Lepidoptera: Gelechiidae), pp. 107-149. In Insect Pests of Cotton (edited by G. A. Matthews and I. P. Tugstell). CAB International, Wallingford, Oxon.

James C. (2008) Global status of commercialized Biotech/ GM crops: 2008 Brief \# 39-2008. International Service for the Acquisition of Agri-biotech Applications Briefs, http: / / www.isaaa.org

Kranthi S. and Kranthi K. R. (2008) Changes in baseline susceptibility of cotton bollworm Helicoverpa armigera (Hubner) (Lepidoptera: Noctuidae) to Cry1Ac toxin from Bacillus thuringiensis. Report of Central Institute for Cotton Research (CICR) submitted to Genetic Engineering Approval Committee (GEAC), Government of India, 1-9.

Navarajan Paul A. V., Ram D. and Parshad B. (1979) Sex determination of pupae of Heliothis armigera Hubner of gram. Indian Journal of Entomology 41, 285-286.

Navarajan Paul A. V., Parshad B. and Gautam R. D. (1987) An artificial diet for Pectinophora gossypiella (Saund.) and Earias vittella Fab. bollworms of cotton. Indian Journal of Agricultural Science 57, 189-192.

Patana R. (1977) Layered Diet for Pink Bollworm Rearing. United States Department of Agriculture, Agricultural Research Service, W-47, 10 pp.

Pearson E. O. (1958) The Insect Pests of Cotton in Tropical Africa. Empire Cotton Growing Corporation and Commonwealth Institute of Entomology, London. 355 pp.

Raulston J. R. (1971) A practical diet containing cotton seed for rearing pink bollworm. Journal of Economic Entomology 64, 1021-1023.

SAS Institute (1997) SAS Software, version 3.2.2. SAS Institute, Cary, NC, USA.

Sims S. R., Greenplate J. T., Stone T. B., Caprio M. A. and Gould F. L. (1996) Monitoring strategies for early detection of Lepidoptera resistance to Bacillus thuringiensis insecticidal proteins, Molecular Genetics and Evolution of Pesticide Resistance. American Chemical Society Symposium Series 645. An American Chemical Society Publication, Washington, DC. pp. 230-242.

Tabashnik B. E., Patin A. L., Dennehy T. J., Liu Y. B., Carrière Y., Sims M. A. and Antilla L. (2000) Frequency of resistance to Bacillus thuringiensis in field populations of pink bollworm. Proceedings of the National Academy of Sciences of the USA 97, 12980-12984. 